\title{
Prevalence of pediculosis capitis and associated factors among schoolchildren in Woreta town, northwest Ethiopia
}

\author{
Henok Dagne ${ }^{1 *} \mathbb{C}$, Awel Aba Biya ${ }^{1}$, Amanuel Tirfie ${ }^{1}$, Walelegn Worku Yallew ${ }^{1}$ and Baye Dagnew ${ }^{2}$
}

\begin{abstract}
Objectives: The aim of the study was to determine the associated risk factors and prevalence of pediculosis capitis among school-aged children in Woreta town, northwest Ethiopia. An institution-based cross-sectional study was carried out on 402 schoolchildren in Woreta town public schools from grades 1 to 4 students conducted from April to June 2018. After selection by simple random sampling, face to face interview and observations were performed using a semi-structured pre-tested questionnaire. Data were entered into EPI Info 7 and exported to SPSS 21 for further analysis. Descriptive results were presented by simple frequency, percentage, and mean. Binary logistic regression was used to identify associated factors. Those variables with a $p$-value $\leq 0.05$ in the multivariable logistic regression were declared as significantly associated with pediculosis capitis infestation.

Result: The prevalence of pediculosis capitis was $65.7 \%$ [95\% Cl 60.01-70.3\%]. Sex of child, age of the child, maternal education, sharing hair comb, knowledge, and attitude towards pediculosis capitis infestation and hygiene practice were significantly associated with pediculosis (a $p$-value $\leq 0.05$ ). Pediculosis infestation is found to be a major public health problem which demands special attention of the community and the government at large particularly the health sector to reduce the problem.
\end{abstract}

Keywords: Pediculosis capitis, Schoolchildren, Ethiopia

\section{Introduction}

Lice are human-specific ectoparasites and blood-sucking insects which are known to cause trench fever, epidemic typhus, and relapsing fever [1-3]. It affects all strata of the society infesting the hair and skin of humans as pediculus capitis (head lice), Pediculus humanus and Phthiris pubis [4]. Infestation by lice is a major public health problem globally. It is most common in resource-limited countries [5]. It is a ubiquitous problem in children [6]. Pediculosis capitis can cause sleep loss, irritation, pruritus, discomfort, secondary bacterial infections (such as impetigo and acute glomerulonephritis), and lymphadenopathy [7, 8]. Head lice infestations can occasionally cause mental

\footnotetext{
*Correspondence: enoch2313@gmail.com

${ }^{1}$ Department of Environmental and Occupational Health and Safety,

Institute of Public Health, University of Gondar (UoG), P.O. Box 196,

Gondar, Ethiopia

Full list of author information is available at the end of the article
}

disorders [9]. Several studies from various regions in the world have reported that pediculosis capitis infestation prevalence varies from country to country. Studies conducted in southeast Iran reported 67.3\% [10], Bangkok, Thailand 23.32\% [11], Bilbao, Spain 9.39\% [12] prevalence of pediculosis capitis infestation among schoolchildren. It is recommended that local research to obtain evidence on epidemiology, knowledge, and attitudes on lice infestation to find effective medications as currently there are no available data on the prevalence of pediculosis capitis in Woreta town [13]. Although pediculosis infestation is a major public health problem, there is lack of evidence in the study area. The study will help authorities to allocate resources and target risk factors to reduce the burden of infestation. Therefore, the current study aimed to assess the prevalence and associated factors of infestation by Pediculus humanus capitis among schoolchildren in Woreta town, 2018. 


\section{Main text \\ Methods \\ Study setting and period}

The study was conducted on schoolchildren in Woreta town public first cycle (grades 1 to 4) elementary schools from April to June 2018. The town is located at 2092 meters above sea level, $589 \mathrm{~km}$ far from Addis Ababa, the capital city of Ethiopia. There were three elementary schools namely Woreta (formerly known as Guaya), Dudemegn and Esteber with a total number of students of 1419, 1320 and 500 respectively.

Study design Institution-based cross-sectional study was employed.

\section{Study population and eligibility criteria}

Schoolchildren from grades 1 to 4 who were available during the period of data collection whose guardians/ parents have given assent and who agreed to participate, and who did not have active head scabies were included.

\section{Sample size determination and sampling technique}

The sample size was determined by using a single population proportion formula [14] with assumptions; $\mathrm{p}=50 \%$ (as there was no previous study in the country), 95\% confidence level $\left(Z_{a / 2}\right)$ and margin of error $(\mathrm{d})=0.05$

$$
n=\frac{\left(z_{\alpha / 2}\right)^{2} p(1-p)}{d^{2}}=\frac{(1.96)^{2} 0.5(1-0.5)}{0.05^{2}}=384 .
$$

Considering $5 \%$ of the non-response rate, the total sample size was 402. Samples were selected by simple random sampling technique and allocated proportionally to the three schools based on the number of students at each school.

\section{Operational definitions}

Pediculosis A child with at least one head louse by wet combing is considered as being infested by pediculosis capitis [15].

Schoolchildren Children attending classes from grades 1 to 4 were regarded as schoolchildren in the current study.

Knowledge Knowledge was assessed by 10 knowledge items with yes/no category. Students who scored mean and above mean of knowledge questions were considered as knowledgeable.

Attitude Attitude was measured by 8 attitude questions with a 5-scale Likert (1-strongly disagree to 5- strongly agree). Children who scored mean and above of the attitude questions were considered as having a good attitude.

Practice Children were asked five practice questions regarding pediculosis capitis prevention behavior. Those children who scored mean and above mean of the practice questions were considered as having a good practice.

\section{Data collection instrument, procedure and quality control}

A pre-tested, semi-structured questionnaire containing socio-demographic variables, behavioral characteristics (knowledge, attitude and practice regarding pediculosis capitis infestation) was used. Wet combing and observation was used to decide whether a child is infested or not according to Wegner [15]. Interview and observation was done by two Environmental health bachelor degree students after receiving training about the data collection tool, techniques, the purpose of the study and ethical issues. The training was given by the principal investigator at University of Gondar, College of Medicine and Health Science.

Reliability The Cronbach's alpha scale for knowledge, attitude and practice questions were 0.84 (good), 0.97 (excellent) and 0.70 (acceptable) reliability, respectively. The overall Cronbach's alpha result was 0.77 (acceptable) [16].

Validity Content validity was ensured by pretesting the data collection tool on 20 students out of the study area. The tool was modified based on the observed findings from the pre-test result. Some questions were rewritten for better understanding of study participants. Words having ambiguous meaning were corrected.

\section{Data processing and analysis}

Data were entered into EPI Info 7 and exported to SPSS 21 for analysis. Mean, frequency and percentage were used for description. A binary logistic regression model was used to identify significantly associated variables at a $\mathrm{p}$-value $\leq 0.05$. During bivariable analysis, variables with a $\mathrm{p}$-value $\leq 0.2$ were candidates for multivariable logistic regression for the final model. Hosmer and Lemeshow goodness-of-fit test was performed.

\section{Result}

Socio-demographic characteristics

Four hundred two schoolchildren with a mean age of $10.19 \pm 1.62$ years participated in this study. About 186 (46.3\%) were males (Table 1). Two hundred and 
Table 1 Sociodemographic characteristics of study participants school Woreta town, $2018(n=402)$

\begin{tabular}{|c|c|c|c|}
\hline Variables & Categories & Frequency & Percent (\%) \\
\hline \multirow[t]{4}{*}{ Student grade level } & Grade 1 & 99 & 24.6 \\
\hline & Grade 2 & 99 & 24.6 \\
\hline & Grade 3 & 100 & 24.9 \\
\hline & Grade 4 & 104 & 25.9 \\
\hline \multirow[t]{2}{*}{ Sex } & Male & 186 & 46.3 \\
\hline & Female & 216 & 53.7 \\
\hline \multirow[t]{3}{*}{ Age } & $5-8$ & 85 & 21.1 \\
\hline & $9-11$ & 230 & 57.2 \\
\hline & $>12$ & 87 & 21.6 \\
\hline \multirow[t]{3}{*}{ Religion } & Orthodox & 291 & 72.4 \\
\hline & Muslim & 108 & 26.9 \\
\hline & Protestant & 3 & 0.7 \\
\hline \multirow[t]{3}{*}{ Fathers education } & Illiterate & 111 & 27.6 \\
\hline & Elementary & 161 & 40 \\
\hline & Secondary and above & 130 & 32.3 \\
\hline \multirow[t]{3}{*}{ Mothers education } & Illiterate & 171 & 42.5 \\
\hline & Elementary & 162 & 40.3 \\
\hline & Secondary and above & 69 & 17.2 \\
\hline \multirow[t]{4}{*}{ Fathers occupation } & Private worker & 153 & 38.1 \\
\hline & Government worker & 64 & 15.9 \\
\hline & Daily labor & 42 & 10.4 \\
\hline & Others & 143 & 35.6 \\
\hline \multirow[t]{4}{*}{ Mother's occupation } & Private worker & 62 & 15.4 \\
\hline & Government worker & 25 & 6.2 \\
\hline & Housewife & 240 & 59.7 \\
\hline & Others & 75 & 18.7 \\
\hline \multirow[t]{4}{*}{ Family size } & 2 to 3 & 21 & 5.2 \\
\hline & 4 to 5 & 206 & 51.2 \\
\hline & 6 to 7 & 136 & 33.8 \\
\hline & $>8$ & 39 & 9.7 \\
\hline
\end{tabular}

thirty-eight (59.2\%) students reported taking bath once per week, 296 (73.6\%) sleep with others, and 187 (46.5\%) share comb (Table 2).

Two hundred and sixty-four (65.7\%) [95\% CI 61.0170.3\%] students were infested by pediculosis capitis.

\section{Factors associated with Pediculosis Capitis infestation}

In bivariable analysis; grade level, sex and age of children, maternal education and occupation, family size, sleeping arrangement, sharing of hair comb, knowledge, attitude and practice towards pediculosis were candidate variables ( $p$-value $\leq 0.2$ ) for multivariable logistic regression. Only age of child, sex of a child, maternal education, sharing hair comb, knowledge, attitude and practice were significantly associated with pediculosis capitis infestation.
Females were 3.29 times $[\mathrm{AOR}=3.29,95 \% \mathrm{CI}(1.94$, 5.59)] more infested by pediculosis capitis than males. The odds of pediculosis capitis infestation was twice among students aged 9 to 11 years than aged above 12 years $[\mathrm{AOR}=2.04,95 \% \mathrm{CI}(1.07 .3 .87)]$.

Students having illiterate mothers were 3.57 $[\mathrm{AOR}=3.57,95 \% \mathrm{CI}(1.74,7.33)]$ times at risk of being infested than those with mother's education greater than elementary level.

Students who shared hair comb were $2.72[\mathrm{AOR}=2.72$, 95\% CI $(1.58,4.69)]$ times being infested than those who did not share hair comb. Those with poor knowledge were $2.51[\mathrm{AOR}=2.51,95 \% \mathrm{CI}(1.24,5.10)]$ times, students with a poor attitude were $2.42[\mathrm{AOR}=2.42,95 \%$ CI $(1.28,4.60)]$ times and children with poor practice were $3.84(\mathrm{AOR}=3.84,95 \% \mathrm{CI}(1.45,10.15)$ times being infested by pediculosis capitis as compared to those having good knowledge, attitude and practice respectively (Table 3).

\section{Discussion}

Lice infestation is a major public health problem to which primary school students are more prone across the globe particularly in developing states. In this study, prevalence of pediculosis capitis was $65.7 \%$. A study conducted in Southeast Iran reported similar findings with prevalence of $67.3 \%$ [10]. The prevalence of the current study is higher than a report from Bangkok, 23.32\% [11], Iran 10.5\% [17], Bilbao 9.39\% [12], central Iran 29.35\% [18], Argentina; 42.7\% [19] and Cambodia 15.1\% [20]. This difference might be related to differences in sample size, geo-cultural and socioeconomic variations. The prevalence in the current study is lower than a study conducted in Ratchaburi reporting $86.5 \%$ prevalence [21]. This difference might be due to sample size and socioeconomic factors.

In the current study sex, age, maternal education, sharing hair comb, knowledge, attitude and practice were significantly associated with pediculosis capitis infestation.

The odds of being infested by pediculosis capitis was 3.29 times higher in female students than males. This disparity is in line with previous studies from Bangkok [11], Iran [17, 22] Argentina [19] and Colombia [23]. This might be due to the habit of female students to have long hairs that can harbor the parasite and have close relationships with other girls, involving multiple and intimate body contact than boys [24]. Where as in another study in Iran the prevalence of pediculosis capitis infestation was not associated with sex of children [25].

Children age level was one of the predictors of pediculosis capitis infestation in the current study. Children aged 9 to 11 years were twice at higher risk of being infested by pediculosis capitis than those aged 12 years 
Table 2 Behavioral characteristics of respondents, Woreta town $(n=402)$

\begin{tabular}{|c|c|c|c|}
\hline Variable & Category & Frequency & Percent (\%) \\
\hline \multirow[t]{2}{*}{ Sleeping arrangement } & Alone & 106 & 26.4 \\
\hline & With others & 296 & 73.6 \\
\hline \multirow[t]{2}{*}{ Sharing of hair comb } & Yes & 187 & 46.5 \\
\hline & No & 215 & 53.5 \\
\hline \multirow[t]{4}{*}{ Frequency of combing hair } & Once a week & 166 & 41.3 \\
\hline & Twice a week & 100 & 24.9 \\
\hline & Thrice a week & 74 & 18.4 \\
\hline & Never & 62 & 15.4 \\
\hline \multirow[t]{2}{*}{ The class situation for learning } & Comfortable & 46 & 11.4 \\
\hline & Not comfortable & 356 & 88.6 \\
\hline \multirow[t]{2}{*}{ Presence of hygiene inspection club } & Yes & 106 & 26.4 \\
\hline & No & 296 & 73.6 \\
\hline \multirow[t]{3}{*}{ Frequency of class inspection } & Once week & 107 & 26.6 \\
\hline & Twice a week & 1 & 0.2 \\
\hline & Never & 294 & 73.1 \\
\hline \multirow[t]{2}{*}{ Water accessibility in the school } & Yes & 29 & 7.2 \\
\hline & No & 373 & 92.8 \\
\hline
\end{tabular}

Table 3 Associated factors of pediculosis capitis in regression of bivariate and multivariate analysis among school-aged children in Woreta town, $2018(n=402)$

\begin{tabular}{|c|c|c|c|c|c|}
\hline \multirow[t]{2}{*}{ Variables } & \multirow[t]{2}{*}{ Categories } & \multicolumn{2}{|c|}{ Pediculosis } & \multirow[t]{2}{*}{ COR $(95 \% \mathrm{Cl})$} & \multirow[t]{2}{*}{ AOR $(95 \% \mathrm{Cl})$} \\
\hline & & Yes & No & & \\
\hline \multirow[t]{2}{*}{ Sex } & Male & 102 & 84 & 1 & 1 \\
\hline & Female & 162 & 54 & $2.47(1.62,3.77)$ & $3.29(1.94-5.59)^{* * *}$ \\
\hline \multirow[t]{3}{*}{ Age in years } & 5 to 8 & 60 & 25 & $1.77(0.94,0.34)$ & $2.19(0.96,5.01)$ \\
\hline & 9 to 11 & 154 & 76 & $1.49(0.90,2.49)$ & $2.04(1.07,3.87)^{*}$ \\
\hline & $\geq 12$ & 50 & 37 & 1 & 1 \\
\hline \multirow[t]{3}{*}{ Mothers education } & Illiterate & 136 & 35 & $5.05(2.76,9.24)$ & $3.57(1.74,7.33)^{* * *}$ \\
\hline & Elementary & 98 & 64 & $1.99(1.13,3.52)$ & $1.68(0.86-3.28)$ \\
\hline & Secondary and above & 30 & 39 & 1 & 1 \\
\hline \multirow[t]{2}{*}{ Sharing hair comb } & Share & 153 & 34 & $4.2(2.67,6.67)$ & $2.72(1.58,4.69)^{* * *}$ \\
\hline & No share & 111 & 104 & 1 & 1.00 \\
\hline \multirow[t]{2}{*}{ Knowledge towards pediculosis capitis } & Poor & 144 & 22 & $6.33(3.78,10.60)$ & $2.51(1.24,5.10)^{*}$ \\
\hline & Good & 120 & 116 & 1 & 1 \\
\hline \multirow[t]{2}{*}{ Attitude towards pediculosis capitis } & Poor & 183 & 35 & $6.65(4.18,10.56)$ & $2.42(1.28,4.60)^{* *}$ \\
\hline & Good & 81 & 103 & 1 & 1 \\
\hline \multirow[t]{2}{*}{ Practice towards pediculosis capitis } & Poor & 80 & 6 & $9.56(4.05,22.59)$ & $3.84(1.45,10.15)^{* *}$ \\
\hline & Good & 184 & 132 & 1 & 1 \\
\hline
\end{tabular}

COR crude odds ratio, $A O R$ adjusted odds ratio, $\mathrm{Cl}$ confidence interval

Significant at ${ }^{*} p \leq 0.05,{ }^{* *} p \leq 0.01,{ }^{* * *} p \leq 0.001$, Hosmer-Lemeshow goodness-of-fit $(p=0.436)$

and above. This might be due to a higher level of personal hygiene practice among children with greater age. This result is supported by previous study done among primary schoolchildren in Kurdistan province [8].

Mothers' education level was one of the predictors of pediculosis capitis infestation among schoolchildren.
Children with illiterate mothers were 3.57 times at higher risk of being infested than children whose mothers' educational status is secondary and above. This is in agreement with other studies [10, 17]. This might be because education is correlated with eagerness and ability to gain new knowledge and knowledge may help to have good 
personal hygiene practice which reduces infestation. However, in other studies maternal education was not associated $[22,26]$.

Students who shared comb were 2.7 times more likely to be infested than those who do not share comb. Sharing articles such as comb was significantly associated with pediculosis infestation in previous studies, too [10, $27,28]$. This is due to the fact that sharing comb is an efficient mechanism of louse and egg transmission. In contrast to this in an epidemiological study conducted in Asadabad, Iran sharing comb was not significantly associated with head lice infestation [26].

The knowledge of students regarding head lice infestation was significantly associated with infestation status. This is in line with a previous study [29]. This may be due to the fact that knowledge deficiency leads to inadequate ability to manage lice infestation [30]. The attitude towards pediculosis capitis and hygiene practice of schoolchildren were also significantly associated with pediculosis capitis infestation in the current study.

\section{Conclusion}

Head lice infestation is a major public health problem and needs educational campaigns targeting mothers and planning of knowledge, attitude and practice improvement strategies by national and regional health authorities.

\section{Limitations of the study}

The limitation of the current study were the inherent weakness of cross-sectional study design to establish cause-effect relationship, recall and social desirability bias.

\section{Abbreviations \\ AOR: adjusted odds ratio; COR: crude odds ratio; Cl: confidence interval; EPI Info: epidemiological information; SPSS: statistical package for social sciences.}

\section{Acknowledgements}

We would like to thank our study participants, school directors, and the University of Gondar and data collectors.

\section{Authors' contributions}

AA, AT, WWY and HD involved in proposal development, participated in data collection, statistical analysis. BD and HD prepared the manuscript. All authors have participated actively in the entire research process. All authors read and approved the final manuscript

\section{Funding}

No funding agent.

\section{Availability of data and materials}

The dataset in the current study is available from the corresponding author upon request.

\section{Ethical approval and consent to participate}

Ethical approval was obtained from the Ethical Committee of the Department of Environmental and Occupational Health and Safety, University of Gondar.
The purpose of the study was clearly explained to the study subjects, to school directors and parents of the students and assent was obtained from them. Written informed consent was obtained. Confidentiality of the information had been maintained at all levels of the study. Students found infested received soap for washing free of charge. Health education was given for students, teachers and school directors after data collection is finalized.

\section{Consent for publication}

Not applicable.

\section{Competing interests}

The authors declare that they have no competing interests.

\section{Author details}

${ }^{1}$ Department of Environmental and Occupational Health and Safety, Institute of Public Health, University of Gondar (UoG), P.O. Box 196, Gondar, Ethiopia.

${ }^{2}$ Department of Human Physiology, School of Medicine, UoG, P.O. Box 196, Gondar, Ethiopia.

Received: 2 May 2019 Accepted: 25 July 2019

Published online: 30 July 2019

\section{References}

1. Brouqui P, Raoult D. Arthropod-borne diseases in homeless. Ann NY Acad Sci. 2006;1078(1):223-35.

2. Raoult D, Birtles RJ, Montoya M, Perez E, Tissot-Dupont H, Roux V, et al. Survey of three bacterial louse-associated diseases among rural Andean communities in Peru: prevalence of epidemic typhus, trench fever, and relapsing fever. Clin Infect Dis. 1999;29(2):434-6.

3. Boutellis $A$, Abi-Rached $L$, Raoult $D$. The origin and distribution of human lice in the world. Infect Genet Evol. 2014;23:209-17.

4. For ERU, Of I. Pediculosis (lice infestation) Frequently asked questions. Natl Inst Commun Dis. 2017:493:4-5.

5. Değerli S, Malatyalı E, Mumcuoğlu KY. Head lice prevalence and associated factors in two boarding schools in Sivas. Turkiye Parazitol Derg. 2013;37(1):32-5.

6. Bonilla DL, Durden LA, Eremeeva ME, Dasch GA. The biology and taxonomy of head and body lice-implications for louse-borne disease prevention. PLoS Pathog. 2013;9(11):e1003724.

7. Doroodgar A, Sadr F, Doroodgar M, Doroodgar M, Sayyah M. Examining the prevalence rate of Pediculus capitis infestation according to sex and social factors in primary school children. Asian Pac J Trop Dis. 2014;4(1):25-9.

8. Vahabi A, Shemshad K, Sayyadi M, Biglarian A, Vahabi B, Sayyad S, et al. Prevalence and risk factors of Pediculus (humanus) capitis (Anoplura: Pediculidae), in primary schools in Sanandaj City, Kurdistan Province, Iran. Trop Biomed. 2012;29(2):207-11.

9. Oh J-M, Lee IY, Lee W-J, Seo M, Park S-A, Lee SH, et al. Prevalence of pediculosis capitis among Korean children. Parasitol Res. 2010;107(6):1415-9.

10. Soleimani-Ahmadi M, Jaberhashemi SA, Zare M, Sanei-Dehkordi A. Prevalence of head lice infestation and pediculicidal effect of permethrine shampoo in primary school girls in a low-income area in southeast of Iran. BMC Dermatol. 2017;17(1):10.

11. Rassami W, Soonwera M. Epidemiology of pediculosis capitis among schoolchildren in the eastern area of Bangkok, Thailand. Asian Pac J Trop Biomed. 2012;2(11):901-4.

12. Magra BG, Goiria OJ, López MI, Pérez RC, Bonet RT, Caturla LJ. Pediculosis capitis: epidemiologic study of 23,624 schoolchildren in Bilbao. Rev Sanid Hig Publica. 1989;63(1-2):49.

13. Speare $R$, Harrington $H$, Canyon D, Massey PD. A systematic literature review of pediculosis due to head lice in the Pacific Island Countries and Territories: what country specific research on head lice is needed? BMC Dermatol. 2014;14(1):11.

14. Arifin WN. Introduction to sample size calculation. Educ Med J. 2013;5:2

15. Wegner Z, Racewicz M, Stańczak J. Occurrence of pediculosis capitis in a population of children from Gdańsk, Sopot, Gdynia and the vicinities. Appl Parasitol. 1994;35(3):219-25.

16. George D. SPSS for windows step by step a simple guide and reference answers to selected exercises. Bacon: Allyn; 2003. 
17. Nejati J, Keyhani A, Kareshk AT, Mahmoudvand H, Saghafipour A, Khoraminasab M, et al. Prevalence and Risk Factors of Pediculosis in Primary School Children in South West of Iran. Iran J Public Health. 2018;47(12):1923.

18. Saghafipour A, Nejati J, Zahraei Ramazani A, Vatandoost H, Mozaffari E, Rezaei F. Prevalence and risk factors associated with head louse (Pediculus humanus capitis) in Central Iran. Int J Pediatr. 2017:5(7):5245-54.

19. Gutiérrez MM, González JW, Stefanazzi N, Serralunga G, Yañez L, Ferrero AA. Prevalence of Pediculus humanus capitis infestation among kindergarten children in Bahía Blanca city, Argentina. Parasitol Res. 2012;111(3):1309-13.

20. Ruankham W, Winyangkul P, Bunchu N. Prevalence and factors of head lice infestation among primary school students in northern Thailand. Asian Pac J Trop Dis. 2016;6(10):778-82.

21. Thanyavanich N, Maneekan P, Yimsamram S, Maneeboonyang W, Puangsa-art S, Wuthisen $\mathrm{P}$, et al. Epidemiology and risk factors of pediculosis capitis in 5 primary schools near the Thai-Myanmar border in Ratchaburi Province, Thailand. 2008.

22. Shayeghi M, Paksa A. Epidemiology of head lice infestation in primary school pupils, in khajeh city, East azerbaijan province, iran. Iran J Arthropod-borne Dis. 2010;4(1):42.

23. López-Valencia D, Medina-Ortega Á, Vásquez-Arteaga LR. Prevalence and variables associated with pediculosis capitis in kindergarten children from Popayán, Colombia. Revista de la Facultad de Medicina. 2017;65(3):425-8.

24. Heukelbach J, Wilcke T, Winter B, Feldmeier H. Epidemiology and morbidity of scabies and pediculosis capitis in resource-poor communities in Brazil. Br J Dermatol. 2005;153(1):150-6.
25. Dehghanzadeh R, Asghari-Jafarabadi M, Salimian S, Hashemi AA, Khayatzadeh S. Impact of family ownerships, individual hygiene, and residential environments on the prevalence of pediculosis capitis among schoolchildren in urban and rural areas of northwest of Iran. Parasitol Res. 2015;114(11):4295-303.

26. Nazari M, Goudarztalejerdi R, Payman MA. Pediculosis capitis among primary and middle school children in Asadabad, Iran: an epidemiological study. Asian Pac J Trop Biomed. 2016;6(4):367-70.

27. Al Bashtawy M, Hasna F. Pediculosis capitis among primary-school children in Mafraq Governorate, Jordan. 2012.

28. Moradiasl E, Habibzadeh S, Rafinejad J, Abazari M, Ahari SS, Saghafipour A, et al. Risk factors associated with head lice (pediculosis) infestation among elementary school students in Meshkinshahr county, North West of Iran. Int J Pediatr. 2018;6(3):7383-92.

29. Kassiri H, Esteghali E. Prevalence rate and risk factors of pediculus capitis among primary school children in Iran. Arch Pediatr Infect Dis. 2016;4(1):e26390.

30. Sidoti E, Bonura F, Paolini G, Tringali G. A survey on knowledge and perceptions regarding head lice on a sample of teachers and students in primary schools of north and south of Italy. J Prev Med Hyg. 2009;50(3):141-9.

\section{Publisher's Note}

Springer Nature remains neutral with regard to jurisdictional claims in published maps and institutional affiliations.
Ready to submit your research? Choose BMC and benefit from:

- fast, convenient online submission

- thorough peer review by experienced researchers in your field

- rapid publication on acceptance

- support for research data, including large and complex data types

- gold Open Access which fosters wider collaboration and increased citations

- maximum visibility for your research: over $100 \mathrm{M}$ website views per year

At BMC, research is always in progress.

Learn more biomedcentral.com/submissions 